Article

\title{
Gender and Social Justice in Urban Agriculture: The Network of Agroecological and Peripheral Female Urban Farmers from São Paulo
}

\author{
Laura Martins de Carvalho ${ }^{1, *(D)}$ and Cláudia Maria Bógus ${ }^{2}$ \\ 1 Program Global Health and Sustainability, Faculty of Public Health, University of São Paulo, \\ Av. Dr. Arnaldo, 715, Cerqueira César, São Paulo 01246-904, Brazil \\ 2 The Faculty of Public Health, University of São Paulo, Av. Dr. Arnaldo, 715, Cerqueira César, \\ São Paulo 01246-904, Brazil; claudiab@usp.br \\ * Correspondence: lauramarcarvalho@gmail.com
}

Received: 29 June 2020; Accepted: 20 July 2020; Published: 22 July 2020

\begin{abstract}
This article analyses women's participation in the 'Network of Agroecological and Peripheral Female Urban Farmers', an agroecological urban agriculture grassroots network in São Paulo, Brazil. The methodology used was participant observation. The following procedures were used to produce the data: participation in three workshops, direct observation, field notes, and an in-depth interview with two of the organizers and three participants. The results show that the Network engendered the formation of a popular feminist collective identity, as it fostered the awareness of oppressive social structures, such as gender inequality and violence against women, of which many participants were survivors. From a technical standpoint, the Network seeks to expand its scope of action, increase the number of participants, establish new partnerships and access multiple sources of funding to obtain greater autonomy from São Paulo City Council.
\end{abstract}

Keywords: women in urban agriculture; gender in urban agriculture; urban agroecology; feminist agroecological grassroots network

\section{Introduction}

Numerous studies have investigated the dynamics of gender issues in urban agriculture in countries like Ghana, Uganda, Zimbabwe, Kenya, Senegal, India, the Philippines, Peru, Argentina, Mexico and Portugal (Hovorka et al. 2009; Delgado 2017). It is recognized that there has been a large increase in the number and protagonism of women practicing urban agriculture (Delgado 2017). However, research on gender issues in urban agriculture in the metropolitan regions of Brazil and in the city of São Paulo is still incipient. Due to socio-political, historical and cultural reasons, women's efforts in urban agriculture are not properly recognized by São Paulo City Council and, therefore, they do not receive the necessary resources and equipment to fully develop their activities (Bellenzani et al. 2019). Furthermore, in large cities of developing countries, population growth associated with increasing poverty, unemployment and gender inequality represents an even greater challenge for local food production, and it is associated with food and nutritional insecurity and governance inefficiency (Hovorka et al. 2009; Cabannes 2012).

The city of São Paulo has 12.5 million inhabitants. It is the most populous city in Brazil, on the American continent, and it is the 4th largest metropolitan region in the world, with 21.5 million people. It has the highest GDP per capita in the country, it is the largest economic hub in Latin America, and is also one of the most unequal cities on the planet: socially, economically and spatially. The territorial occupation and expansion of São Paulo was marked by a rapid urbanization process during which there was little or no integration of natural ecosystems. In addition, there was no project or program for 
the inclusion of vulnerable populations. In this sense, the city still faces enormous challenges related to the concentration of public services and economic activities in central regions; the marginalization of the periphery, characterized by social and racial exclusion; and the lack of the integration of green areas, characterized by environmental and public health problems (Rolnik and Heitor 2001; Oliveira 2017).

Given the large social, economic and environmental challenges the city faces, urban agriculture was conceived of as one of the solutions for these problems. It first became a topic of interest for the public power in the 1980s, when the government of São Paulo elaborated on and implemented food production programs in the electricity transmission tower land prevalent in peripheral regions of the city. In 2004, urban agriculture was institutionalized with the elaboration of the São Paulo Urban and Peri-Urban Agriculture Program (PROAURP), whose objective was to make agriculture a means of employment and income generation, to stop hunger and to promote social inclusion. However, the implementation of the program was stunted due to lack of political interest (Oliveira 2017). In the opposite direction, since 2010, urban agriculture activists and urban agroecology groups from central areas of the city have been pushing forward a new agenda of environmental and citizens' rights to take to the policymakers of São Paulo's City Council. The activists' actions resulted in the approval of a bill in 2015 that guarantees the participative management of town squares such as organic community gardens of an educational nature (Nagib 2018). Nonetheless, community gardeners and urban farmers from peripheral areas have remained absent from sustainability public councils in the last decade (Bellenzani et al. 2019).

To stimulate the participation of marginalized women in the Sustainable and Solidary Rural Development Council, two feminist civil servants proposed a working group called 'Women and Agroecology' in February, 2018 as a means to implement gender inclusion, as highlighted in the final report of the First Municipal Conference on Sustainable and Solidary Rural Development of the City of São Paulo: "we understand that all policies, strategies, programs and projects related to agroecological development must be guided by broad and democratic participation, respect for the specificities of the territories and account for gender and ethnicity issues" (São Paulo 2016, p. 19, author's translation). This working group aimed at reaching, mainly, women from peripheral regions of São Paulo. These territories have remnants of Atlantic Forest, countless water sources and large food production areas. They are also inhabited by the lowest socioeconomic status members of the city, lack public services, and face high levels of violence and social exclusion-particularly experienced by women of color (Oliveira 2017; Nagib 2018; Bellenzani et al. 2019).

The 'Women and Agroecology' working group was approved by the Sustainable and Solidary Rural Development Council, and soon afterwards a partnership was established between the working group and the grassroots feminist organization, SOF (Sempreviva Organização Feminista). SOF conducts reference work with women and agroecology (Jancz et al. 2018). The objective of the partnership was to construct a socio-technical network of female community gardeners and urban farmers, together with agroecological technicians, civil servants, and researchers in the city of São Paulo, with the following purposes: (a) to identify the challenges the participants face, (b) to understand how they organize their activities, (c) to stimulate their economic autonomy and (d) to promote discussions on gender equality,-guided by feminist ideas and the agroecological framework and practices (Bellenzani et al. 2019). This article ${ }^{1}$ has five objectives: (i) to describe and analyze the activities proposed by the organizers of the working group and SOF; (ii) to describe and analyze the sites where the activities took place, looking specifically at environmental, social and economic attributes; (iii) to analyze the interaction among the participants; (iv) to reflect on the effects of the workshops on the

1 This article is an expanded and modified version of a paper presented at the IV Encontro Latinoamericano de Agricultura Urbana e Periurbana, held at the Universidade Federal de Santa Catarina (UFSC), 6 to 9 November 2019. 
participants; and (v) to identify the challenges the Network faces, the areas in need of support and what forms that support could take ${ }^{2}$

\section{Materials and Methods}

The methodology used was participant observation. This type of methodology is widely used in qualitative research that seeks to understand subjects and their activities in the context where they take place, thus allowing researchers to gather elements that allow an inductive and comprehensive analysis of the phenomenon studied. In this direction, it is possible to acquire more detailed and accurate information about the subjects and the roles they perform, as well as to monitor the unfolding of unforeseen situations during field work. Furthermore, qualitative methods are marked by the construction of a social reality which has cultural significance and focuses on interactive processes (Spradley 2016). Data production was performed based on a variety of procedures to capture the complexity of the elements that make up the female agroecological urban agriculture scenario in the periphery. The steps and procedures adopted to produce data were: (i) participation in three workshops organized by the Network; (ii) direct observation of the participants' interactions; (iii) notes taken on the sites where the workshops took place; (iv) in-depth interviews with two organizers and three participants ${ }^{3}$.

\section{Results}

\subsection{The Guiding Concepts}

The workshops were guided by agroecological principles, practices and feminist self-organization. Agroecology has multiple meanings and applications. It is a science, a set of agricultural practices and a social movement that consists in the application of ecological concepts for the design and management of sustainable agroecosystems. It integrates traditional and scientific knowledge, and it considers the socioeconomic, cultural and specific aspects of local territories. As agroecology is based on sustainable practices, it involves the ecological management of natural resources and forms of collective social action, from production to the final consumer. It plays a fundamental role in agricultural and social development due to the various benefits it provides, such as quality of life for the farmers, organic food, the valorization of agricultural workers, product traceability and environmental conservation. It is a technique that refuses the use of pesticides, inputs and products that kill living soil organisms, contaminate water and harm other living beings that compose the ecosystem. From an epistemological standpoint, agroecology is linked to a philosophy of respect for the environment and for human beings. For these reasons, those who practice agroecology have, as a premise, a mentality of considering the collective, not only the individual. It is the very opposite of agribusiness models (Altieri 2012).

As agroecology is a system that considers all the components of the food production system, it contributes to provide visibility to the work developed by women, which is fundamental for the system's sustainability and for the family's reproduction. It is vital to recognize the historical role of feminism in the process of women's self-organization, which has had, as one of its results, incorporated gender into the agenda of multiple social movements and grassroots organizations. The application of feminism to agroecology goes beyond the instrumental view of food production, as it proposes practices and reflections that contribute to women's struggles for rights, autonomy, and emancipation from cultural and historical oppression (Siliprandi 2009; Altieri 2012; Bellenzani et al. 2019).

2 This article discusses part of the results of a broader investigation that analyzes the social production of urban agriculture in a socially vulnerable region of the city of São Paulo, conducted since May 2017. For this article, specifically, only the data regarding the activities of the Network is described and analyzed.

3 The Faculty of Public Health of the University of São Paulo requires that subjects who accept to participate in an interview for any research must sign a free and informed consent form, explaining the research objectives and authorizing the reproduction of their statements in the text. Five women agreed with the terms of participation and were interviewed. 
When analyzed in Brazilian rural and urban realities, agroecological movements unearth historical gender inequality and racial injustice. These practices demonstrate the need for fundamental transformations in social and economic structures to guarantee democracy, gender equality, citizenship, and environmental sustainability (Altieri 2012). Furthermore, Brazil is a country that has the fifth highest rate of feminicide in the world (Meneghel and Hirakata 2011; ONU Mulheres 2016). The 2015 Map of Violence shows that, from 2003 to 2013, the number of murders of women of color grew by $54 \%$ in the country. In the same decade, there was an increase of $190.9 \%$ in the victimization of women of color (Waiselfisz 2015) In this sense, agroecology also seeks to eliminate the discrimination to which women are subjected by machismo, racism, ethnocentrism, lesbophobia and other forms of inequalities that culminate in violent deaths, especially for women of color.

\subsection{The Workshops}

\subsubsection{First Workshop}

The first workshop took place at the Sempreviva Organização Feminista office, on 18th May 2018. It was attended by 27 women-twenty community gardeners and farmers from socially vulnerable areas of São Paulo, four civil servants, two agroecological technicians and one researcher. The workshop started with a collective breakfast, followed by a round of individual presentations. In this moment, a woman of color from the periphery spoke about the physical and psychological violence she has suffered for years at the hands of her husband. Her report provoked a collective cry that evoked empathy for the survivor and anger towards the perpetrator. The role of emotions in feminist collective action, and in social movements, is recognized as an integral aspect of this type of dynamic (Gamson 1992; Buechler 1995; Taylor 1995).

When emotions are recognized as elements that drive the collective mobilization process, two emotions often emerge: a sense of injustice and anger, which are a legitimate expression of moral indignation and righteous anger directed toward the source of injustice (Hercus 1999). Furthermore, a study conducted with survivors of sexual violence demonstrated that identifying and expressing anger helps women to understand the social forces that shape the existence of perpetrators and that allow their crimes to continue (Fraser 1996). The sources of injustice against women are historical; it exists practically in all societies, and stem from a system of the domination and exploitation of women, in which men are the proponents, agents and subjects of rights, including and mainly being the holders of rights over women's bodies. The structuring system of domination, exploitation and control over women's body is called patriarchy (Saffioti 2015; Gangoli 2017).

After the individual presentation, participants were divided into five groups and received cardboard and modeling clay to express themselves on their relationship with agroecological urban agriculture in their localities. This dynamic enabled the disclosure of a plurality of situations and practices. During the interactive process, similarities emerged in relation to the potentials and challenges they face. Data were organized into four axes and systematized in relation to the elements that shape their experiences in the community gardens or urban farms:

- Urban agriculture as a source of income-in six cases, urban agriculture was the main source of income. In four cases, it was a complementary source of income. In five cases, there was a desire for urban agriculture to be the main source of income, but it was not yet.

- Family support-in six cases, the husband or partner was supportive of the wife's work in urban agriculture, but he did not accept it as her main source of income. In five cases, the husband or partner was against the wife's work in urban agriculture. In three cases, the husband or partner questioned the wife's moral conduct in the community garden and devalued her work.

- Affective and existential —all of the women spoke of a feeling of love for the land, which can be translated as an affectionate relationship they have with cultivation, flowers, plants, and with the earth itself. Three women spoke of how they discovered a new meaning for their lives due to their involvement with urban agriculture. Eight of them were born in rural regions of Brazil and 
learned how to cultivate with their families. In this sense, the return to agriculture in the city was also permeated by childhood memories.

- Time management-having the garden or farm close to their home allowed greater flexibility in relation to the time devoted to domestic work and childcare, and the time dedicated to working in the community garden or urban farm.

After that, another activity was carried out, aiming at composing propositions about the needs of women in urban agriculture, to be incorporated as policy recommendations into the Municipal Plan for Sustainable Rural Development. The results were:

- The impact of urban agriculture on health—in three cases, working in the community garden or urban farm caused a negative impact on the body due to use of tools that did not correspond to the women's physiognomy. In two cases, the strenuous physical work led to orthopedic problems. The positive impacts were weight loss, in five cases; improvements in blood pressure, in three cases; and an increased sense of well-being, in three cases. There were also four cases of improvement in mental health condition, such as overcoming depression.

- Access to financial incentives-all the women mentioned the difficulty in accessing financial incentives offered by São Paulo City Council due to a lack of transparency and the bureaucracy involved in the process.

- Land access-all the women were unaware of the negotiation process between landowners and public authorities regarding the land lease agreement, which is the instrument that legally enables agricultural activity in the city.

Both activities allowed the recognition of common elements-potentials and challenges-and elicited a desire to visit the community gardens and the urban farms where the participants work. Given the territorial complexity and the large distances to peripheral areas, it was decided, in common agreement, that the workshops would take place in community gardens or urban farms with the capacity to welcome a group of approximately 30 people. The locations would be proposed by the participants.

The interactive process of listening to the women's experiences with agroecological urban agriculture made it possible to recognize the formation of bonds of solidarity among the participants and the creation of a sense of collective identity-agroecological female urban gardeners or farmers-which corroborates with data from studies on the role of common elements in feminist practices that assign meaning to women's lives, who recognize themselves as a category based on shared experiences and, thus, establish bonds that strengthen their collective social action (Taylor 1995; Hercus 1999; Fominaya 2010).

The organizers created two WhatsUp groups: one with the purpose of exchanging information about the workshops, advertise courses and related events to agroecological urban agriculture; and another group, to organize and implement the workshops.

\subsubsection{Second Workshop}

A collective of nine women urban gardeners called Mulheres do GAU offered to hold the second workshop on 23 June 2018 at the community garden Viveiro Escola União de Vila Nova (Figure 1), based in the district of São Miguel Paulista, which is the second largest socially vulnerable area of the city. This community garden is located 25 min' walk from São Miguel Paulista train station, and it has few public transport services. A meeting point was organized at the metro station that gives access to the train station. At this meeting point, there was man who wanted to participate in the workshop. His presence raised questions regarding the participation of men. Three women argued that the workshop is a space where women also talk about sensitive issues such as abuse, harassment and violence of all kinds, and they could feel intimidated or not encouraged to open up about these issues in the presence of men. Given that some of these women were and some still are victims of domestic violence, it was decided that men could not participate in the workshops. The only exception referred to women with small children, who may bring the boys. 


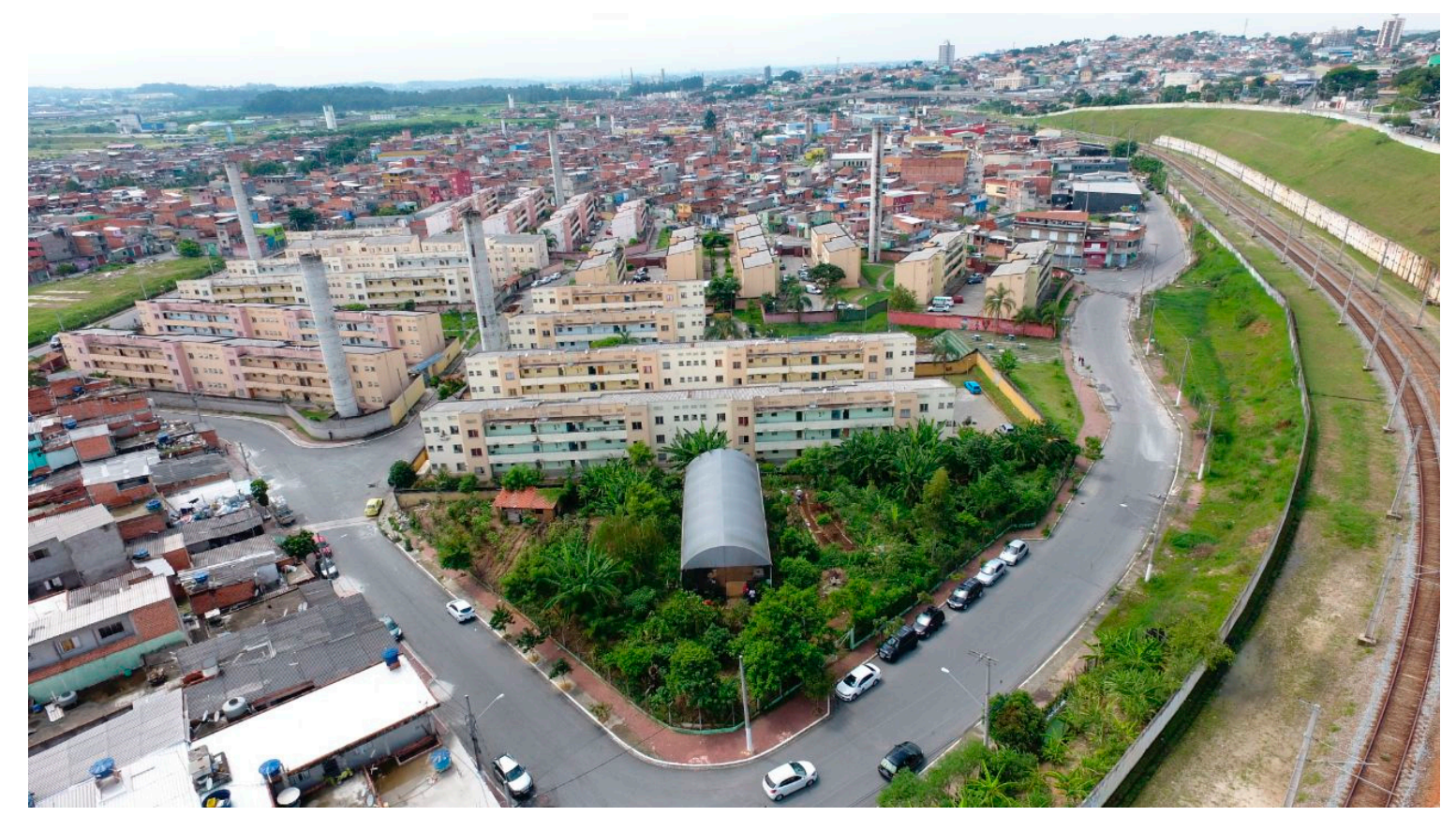

Figure 1. Aerial picture of the community garden Viveiro Escola União de Vila Nova. Source: CDHU/SSARU, 2018.

The refusal to accept men's participation in the workshops can be interpreted as a resistance to social mechanisms that, historically, have allowed men to retain hegemony in public and decision-making spaces, and in the exercise of power. This data corroborates with questions that have already been extensively investigated regarding inequalities between men and women in decision-making spaces, with obvious disadvantages for women (Saffioti 2015; Gangoli 2017). After the first workshop, husbands, partners, researchers, and other men manifested interest in participating in the workshops, and received 'no' as an answer, which is uncommon for Brazil's macho culture. From a relationship culture standpoint, men are taught to have access to wherever the wife or partner goes, and it is still highly uncommon for women to attend meetings or workshops organized by women and for women exclusively (Saffioti 2015). Men's understandings of the workshops were widely different. A few of them supported the participation of their wife or partner, while others felt uncomfortable, to the point of not allowing them to attend the workshops. A participant reported on her husband's attitudes about her participation in the workshops: "If I don't impose myself, I won't participate. If it were for him [the husband], I wouldn't be here. He says that I come here waste my time. He doesn't understand that these workshops are important to me and he doesn't support my choices" (author's translation) ${ }^{4}$.

This workshop was attended by 31 women, of whom three brought small children. A nutrition teacher, three nutrition graduate students and three indigenous women from the Tapé Mirim and Krukutu villages, part of the Tenonde Porã indigenous territory, of the Mbya Guarani indigenous ethnic group, located in the southern end region of São Paulo, were also present. The individual presentation round was held, and the organizers proposed an activity based on the sexual division of labor by employing the 'clock methodology' to display women's and men's activities over the course of a day (Jancz et al. 2018). The participants were divided into two groups. One group designed a clock for their activities (Table 1), and the other designed a clock for the activities of men, taking their partner or husband as reference (Table 2).

4 Verbal information extracted from an in-depth interview with an urban farmer, participant of the Network's workshops. The interview was conducted on 27th July 2018. 
Table 1. Women's daily activities.

\begin{tabular}{ll}
\hline \multicolumn{1}{c}{ Time } & \multicolumn{1}{c}{ Activities } \\
\hline 7:00 a.m. & wake up, brush teeth, prepare breakfast, wake up the children, tidy the bedrooms. \\
\hline 8:00 a.m. & drink coffee, feed the children, do the laundry, prepare lunch. \\
\hline 08:30 a.m. & tidy the leaving room, go work by public transport \\
\hline 09:30 to noon & work \\
\hline Noon & pay rent and other utility bills at the bank, buy toiletries \\
\hline 12:30 p.m. & eat lunch quickly and return to work \\
\hline 1:00 p.m. to 7:00 p.m. & work \\
\hline 7:00 p.m. & grocery shopping \\
\hline 8:30 p.m. & arrive at home, clean up the mess \\
\hline 9:00 p.m. & prepare dinner and play with the children \\
\hline 10:00 p.m. & serve dinner, clean the kitchen, prepare everything for the next day (children's \\
\hline 11:00 p.m. & give attention to the partner or husband \\
\hline Midnight & take a shower and go to sleep \\
\hline
\end{tabular}

Table 2. Men's daily activities.

\begin{tabular}{ll}
\hline \multicolumn{1}{c}{ Time } & \multicolumn{1}{c}{ Activities } \\
\hline 06:00 a.m. & wake up, hygiene and personal care \\
\hline 07:00 a.m. & have breakfast \\
\hline 08:00 a.m. & go to work by car \\
\hline 09:00 a.m. to 6:00 p.m. & work with coffee break in the morning and in the afternoon with one-hour lunch \\
\hline 06:30 p.m. & pick up the children at school, buy bread \\
\hline 07:00 p.m. & arrive at home, play soccer with friends, or go to the gym \\
\hline 08:30 p.m. & take a shower, watch TV, have dinner \\
\hline 11:00 p.m. & give attention to the partner or wife \\
\hline Midnight & go to sleep \\
\hline
\end{tabular}

The first table shows that women have a double workday. In addition to formal work-whether in the community garden or in other job-women were also responsible for all domestic work, which generated a heated debate about gender inequality in domestic labor. This unequal distribution of domestic work is a historical construct of the patriarchal system, which attributed to women the functions of reproduction and domestic care. In economic terms, the capitalist system conceived it as part of the non-market system; that is, unpaid labor. According to the logic of wage labor and from a historical standpoint, domestic work has not been considered work, and therefore, there is no value given to women's work, which is considered free (Fougeyrollas-Schwebel 1999). From a cultural and religious standpoint, domestic labor in Brazil is conceived as a wife's realization of her 'love for the family', not as work. These inequalities led to systematic and systemic practices of the "material appropriation of women's workforce by men, whatever their family status-wives, mothers, daughters, sisters" (Fougeyrollas-Schwebel 1999, p. 64, author's translation).

After this activity, lunch was served-with various dishes prepared with the products from the garden-in the kitchen of the site, with the garden's produce. During lunch, participants talked, laughed and, in a relaxed atmosphere, reflected on their experiences with their community gardens 
or urban farms; cultivation, their care for their children, their relationship with their partners, and how they juggle multiple demands. In this interactive process, bonds of friendship and solidarity strengthened. It was noted that, although some women had traumatic experiences with the partner or husband, some spoke positively of them, saying that they help at home, and support their professional and personal choices. After lunch, three women guided the participants around the site, showing vegetables, and greens beds, tropical fruit trees and medicinal plants that they cultivate. They explained the techniques employed to find out which plants are edible, and which are not-by trying them out-while telling the history of the place. All women working in this community garden have indigenous or African ancestry; they are deeply religious, have low level of formal education, and two of them are completely illiterate. Although they did not have formal training in horticulture, they deconstructed notions about knowledge acquisition, as illustrated in the speech of one of them: "When I am asked where I learned about medicinal plants I say that the earth gave me the certificate [laughs]. I don't have a certificate of this, I don't have a certificate of that... but God teaches me a lot and we learn here every day" (author's translation) ${ }^{5}$.

Since March 2018, Mulheres do GAU started receiving technical support from a housing and urban development company (CDHU-Companhia de Desenvolvimento Habitacional e Urbano do Estado de São Paulo) for the management and accounting aspects of the community garden. Since then, they have expanded widely their scope of services. In addition to cultivation of greens, vegetables, and fruits, sold locally and in other agroecological markets in the city, they have a kitchen where they produce and sell cookies, cakes, breads, jams, spreads, and many other delights. Some of these products are vegan, and all are natural. Mulheres do GAU offer workshops about vegetable gardens in small spaces in educational and training centers, in municipal schools in the region, and in other public and private institutions located in the central regions of the city, where they also sell their products. They provide catering services to large companies, and constantly seek other potential partners and customers in various regions of São Paulo. Since 2018, they have gained a great deal of attention from mainstream media, and started participating in programs on open television channels, YouTube channels, community radios and newspapers articles, among others.

After the visit, the participants agreed on the first technical need of the Network: learning about the production, management, treatment and use of medicinal plants. At the end of the workshop, three indigenous women proposed to host the next workshop at the Guarani Kalipety indigenous village, based in the Tenonde Porã indigenous territory, at the southern end of São Paulo city. After this workshop, the far-right candidate Jair Messias Bolsonaro won the Brazilian presidential election on 28th October 2018. In his presidential campaign, he extolled the country's military dictatorship, defended torture, and threatened to arrest or exile his political opponents. Moreover, he is fond of making misogynistic, racist, homophobic, and transphobic comments. The elections had shaken the Network, which, faced with an already incipient scenario of resources, policies, services and public equipment for women in urban agriculture, they saw their achievements threatened and also feared an increase in violence against women. Faced with this turbulent political scenario, the Network decided to hold the fourth workshop in a peri-urban settlement of the landless movement Movimento dos Trabalhadores Rurais Sem Terra (MST), Comuna da Terra Irmã Alberta, located in the northwest end region of São Paulo city (Bellenzani et al. 2019).

\subsubsection{Fifth Workshop}

The fifth workshop took place on 16th February 2019, at the community garden Instituto Lia Esperança, based next to Jequitibá State Park, at the northwest end of São Paulo, a place that is difficult to reach. The organizers arranged a car sharing, so that all of the participants could arrive at the place.

5 Verbal information extracted from an in-depth interview with an urban farmer, participant of the Network's workshops. The interview was carried out on 25th June 2018. 
In total, 28 women participated-four civil servants, three researchers and twenty-one urban farmers and community gardeners from the peripheral regions of São Paulo. In the presentation round, the community garden's leader told the history of the place and her life trajectory. She comes from a humble family from a rural background area and has low level of formal education. Despite that, she has won a sustainability award at an international design event held in Mexico City, even though she did not have a formal degree, as she recalled: "could you imagine that someone like me, with no degree in architecture ... I am not a designer, I am not an engineer, but I won this award because of this community garden. This place is my life and I work here entirely and relentlessly despite all difficulties". She emphasized the social learning aspect of the community garden, saying that "no one knows more than anyone. Over here we learn by doing things, we learn together, it's all together" (author's translation) ${ }^{6}$. This community garden has won several awards, nationally and internationally, and the leader has participated in many Brazilian television programs.

A guided tour of the place was carried out and a variety of non-conventional food plants (NCFP Non-Conventional Food Plants) were shown. The space has a communal kitchen, a play space for children, a bio-constructed oven for pizza baking, a plant nursery, an orchid nursey and several beds for cultivating greens and vegetables. After the guided tour, lunch was served-with food produced on site- and the participants were divided into four groups to discuss the demands and challenges that the community gardens and urban farms faced in their localities. The groups also discussed the challenges and potentials of the Network itself. The results were systematized in six axes:

- Valorization and training - the demand for the valorization of the community gardens' and urban farms' food produce; the valorization of oneself and other community gardeners and urban farmers; the recognition of the community gardeners' and urban farmers' work; training to add value to food; training to process food (cakes, flours, jams, etc.).

- Marketing-obtaining organic certification and a license to have access to sales in large consumer markets, enabling commercialization in urban settlements.

- Articulation-greater mobilization within the communities; greater union of the various communities in the whole city; more teamwork.

- Challenges-dealing with frequent threats and moral harassment; uncertainty about the land's lease agreement; uncertainties regarding the continuity of the projects; dealing with bureaucracy related to the spaces' infrastructure (lack of water, electricity, sewage and proof of residence); the low level of education of the community gardeners and urban farmers in the peripheral areas.

- Objectives-achieving greater autonomy in the management aspects of the community garden; learning alternative methods for pest control and soil preparation; search for funding sources.

- Potential-the creation of a social map of food production and solidary consumption networks in the whole city of São Paulo; establishing new partnerships; promoting the use of agroecological booklets; the sharing of knowledge, seedlings and seeds.

\subsubsection{Consolidation of the Network}

At the end of the fifth workshop, the Network's participation in the 2019's Women's March Global was discussed, and all of the participants of the Network attended. After that, the organizers set up a Facebook page ${ }^{7}$ to keep record, disseminate, expand the reach of the Network publicly, increase its scope of activities, and consolidate the Network. A first attempt was made to access private funding. All of the activities of all of the workshops were systematized, and a future action plan was prepared to meet the criteria of the registration form. However, the application was unsuccessful.

6 Verbal information extracted from the leader's presentation at the community garden on the fifth workshop of the Network, held on 16th February 2019.

7 Available online: https://www.facebook.com/agricultorasperifericaspaulistanas/ (accessed on 21 June 2020). 
All of the workshops were made possible due to contributions of the participants, such as donations of money for lunch and transport. In the final discussions, women's self-management and women's autonomy based on feminism and agroecology continued to be the guiding principles of the workshop's planning, with a view to encourage women's greater participation and representativeness, both in public councils and in public calls for food acquisition in public institutions, such as schools and day care centers. Logistics issues such as transport remained a challenge, in view of the location of the community gardens or urban farms in peripheral areas. The possibility of establishing partnerships with local businesses owners to obtain donations of materials was also discussed.

In September 2019, the Sustainable and Solidary Rural Development Council of São Paulo City Council launched invitations to urban farmers and community gardeners from all of the regions of the city to offer clarifications about the Council's election, held in December 2019. The election was attended by two female farmers and one male farmer from the southern region, eight female farmers and fourteen male farmers from the northern region, nine female farmers from the eastern region, and other representatives of civil society organizations involved with urban agriculture, in which one representative of the Network was present. In total, 22 women attended the election, of which 18 attended the workshops. However, although the participation of women (and men) has increased significantly, which represents a huge advance in terms of popular participation, there has been no progress in terms of technical improvements and financial contributions to urban agriculture.

In two years of activities, the Network has brought together more than 150 women, thus enabling the expansion of spaces for participation, knowledge exchange about cultivation techniques, the strengthening of solidarity bonds, and the recognition of the multiplicity of situations in which women are involved in agroecological urban agriculture in peripheral areas. According to one of the organizers of the Network, the wide participation of women in the Sustainable and Solidary Rural Development Council of São Paulo City Council's election was also due to the work of the Network.

\section{Discussion}

This study investigated the activities carried out in three workshops that took place between May 2018 and February 2019, organized by the Network of Agroecological and Peripheral Female Urban Farmers from São Paulo. The methodology used was participant observation; two organizers and three participants were interviewed.

\subsection{The Challenges}

All of the urban farmers or community gardeners demonstrated an increasing need to assume operational aspects of community gardens or urban farms; that is, to build conditions to manage the sites with greater autonomy. However, the low level of education of the participants is one of the factors that hinders them from taking full ownership of management aspects and filling out funding applications forms. The unequal distribution of domestic work is also detrimental to their development in urban agriculture once their time is taken by these activities. From a technical standpoint, the uncertainties regarding the continuity of the projects, the bureaucracy involved in the infrastructure of setting up a community garden or urban farm, and difficulties with logistical aspects furthers the challenges the women face. As the results demonstrate, women's work in urban agriculture is still not properly recognized by public authorities, and they do not receive resources to fully develop their potential. The Network seeks to fill this gap. However, policy implementation is slow.

\subsection{Strengthening Women's Political Participation}

The development of urban agriculture by São Paulo City Council is marked by inefficiency and interruptions. Despite the cultural and technical difficulties, the increasing participation of women in the Sustainable and Solidary Rural Development Council, assisted by the Network, helps to stimulate the debate on gender equality and transform female urban farmers and community 
gardeners into political subjects. In addition, women's participation in the Sustainable and Solidary Rural Development Council sheds light on the central difficulties that hinder the development of urban agriculture in the whole city, which are: the access to land, the lease contracts, and the specific challenges of peripheral regions, since women of color are the most exposed to social vulnerabilities and violence in these regions.

Since many participants were survivors of violence of all kinds, their participation in the workshops enabled the enunciation of an agroecological popular feminist identity, which is fostered by a sense of belonging to a reference group, and the recognition of their work in urban agriculture as a means of emancipation from oppressive and excluding social structures. Moreover, in a sexist society that insists on keeping women away from public and decision-making spaces, naturalizing gender inequalities, and not providing the necessary resources for women's personal and professional fulfillment, agroecological feminist self-organization impacted positively on the participants' sense of self-worth. It has also shown the value of their work, and it has stimulated their participation in the Sustainable and Solidary Rural Development Council, which has triggered processes of reducing both social and gender inequality, and has enabled greater visibility of the challenges that women face in urban agriculture in the city of São Paulo.

\subsection{Limitations and Future Research}

There are neither quantitative nor qualitative data on gender issues in urban agriculture in the city of São Paulo; therefore, it is not possible to identify whether women have greater numerical representation. Given the large distances of the city and the insufficiency of public transport, the community gardens or urban farms in the peripheral areas can be difficult to reach, which would require long-term research to capture the complexity of the urban agriculture scenarios in these regions.

In addition, urban agriculture in the city of São Paulo has not been yet investigated under the lens of intersectional theory, which focuses on the overlap of social identities and related systems of oppression, domination and discrimination. This framework can assist us in understanding how injustice, systemic and systematic social inequality occur on a multidimensional basis. Given the deeply unequal, unjust and racist structures of Brazilian society and its current far-right political scenario, the employment of this framework for future research in peripheral regions is suggested, as these regions are inhabited mostly by women of color with low levels of education, and many subject to violence.

Author Contributions: Conceptualization, L.M.d.C.; Data curation, L.M.d.C.; Formal analysis, L.M.d.C.; Investigation, L.M.d.C.; Methodology, C.M.B.; Supervision, C.M.B.; Validation, C.M.B. All authors have read and agreed to the published version of the manuscript.

Funding: This research was funded by Coordenação de Aperfeiçoamento de Pessoal de Nível Superior (CAPES):88882.378274/2019-01.

Conflicts of Interest: The authors declare no conflict of interest.

\section{References}

Altieri, Miguel Altieri. 2012. Agroecologia: Bases Científicas Para Uma Agricultura Sustentável. Terceira edição. São Paulo: Editora Expressão Popular and AS-PTA, pp. 15-49, 103-59. ISBN 978-85-7743-1915.

Bellenzani, Maria Lúcia Ramos, Coleta Flávia Bigai, and Iyusuka Sheyla Saori. 2019. Mulheres agricultoras em São Paulo-SP: Tecendo a teia da agroecologia nas periferias paulistanas. In Colóquio Internacional Feminismo e Agroecologia 3. Recife: UFRPE.

Buechler, Steven. 1995. New social movement theories. The Sociological Quarterly 36: 441-64. [CrossRef]

Cabannes, Yves. 2012. Pro-Poor Legal and Institutional Framework for Urban and Peri-Urban Agriculture. Roma: Food and Agriculture Organization of the United Nations-FAO, ISSN 1014-6679.

Delgado, Cecília. 2017. Agricultura urbana, espaço de protagonismo feminino. Dinâmicas e potencialidades. Faces de Eva 37: 63-81. 
Fominaya, Cristina Flesher. 2010. Collective Identity in Social Movements: Central Concepts and Debates. Sociology Compass 4: 393-404. [CrossRef]

Fougeyrollas-Schwebel, Dominique. 1999. Trabalho doméstico, serviços domésticos. In O Trabalho das Mulheres: Tendências Contraditórias. Cadernos Sempreviva. Textos Para a Ação Feminista. Edited by Nalu Faria and Miriam Nobre. São Paulo: SOF Sempreviva Organização Feminista, pp. 62-71. ISBN 85-86548-065.

Fraser, Skye. 1996. Reclaiming Our Power, Using Our Anger: Working in the Field of Sexual Violence. In Women and Violence: Working for Change. Edited by Rosamund Thorpe and Jude Irwin. Merickeville: Hale \& Iremonger, pp. 162-72.

Gamson, William. 1992. The social psychology of collective action. In Frontiers in Social Movement Theory. Edited by Aldon D. Morris and Carol M. Muellere. London: Yale University Press, pp. 53-76.

Gangoli, Geetanjali. 2017. Understanding patriarchy, past and present. Journal of Gender-Based Violence 1: 127-34. [CrossRef]

Hercus, Cheryl. 1999. Identity, emotion and feminist collective action. Gender \& Society 13: 34-55.

Hovorka, Alice, Zeeuw Henk, and Njenga Mary, eds. 2009. Chapter 1: Gender in urban agriculture: An introduction. In Women Feeding Cities: Mainstreaming Gender in Urban Agriculture and Food Security. Rugby: RUAF Foundation, Practical Action Publishing, Schumacher Centre for Technology and Development, pp. 1-30. ISBN 9781853396854.

Jancz, Carla, Gláucia Marques, Miriam Nobre, Renato Moreno, Rosana Miranda, Sheyla Saori, and Vivian Franco. 2018. Práticas Feministas de Transformação da Economia. Autonomia das Mulheres e Agroecologia no Vale do Ribeira. São Paulo: SOF Sempreviva Organização Feminista, p. 84. ISBN 978-8586548-291.

Meneghel, Stela Nazareth, and Vania Naomi Hirakata. 2011. Femicides: Female homicide in Brazil. Revista de Saúde Pública 45: 564-74. [CrossRef] [PubMed]

Nagib, Gustavo. 2018. Agricultura Urbana como Ativismo na Cidade de São Paulo, Primeira ed. São Paulo: Annablume, ISBN 978-85-391-09104.

NCFP (Non-Conventional Food Plants). 2007. In Portuguese PANCs_Plantas Alimentícias Não Convencionais. Ph.D. thesis, Faculdade de Agronomia. Programa de Pós-Graduação em Fitotecnia-Universidade Federal do Rio Grande do Sul, Porto Alegre, Brazil; 562p.

Oliveira, Lya Cynthia Porto. 2017. Redes, Ideias e Ação Pública na Agricultura Urbana: São Paulo, Montreal e Toronto. Ph.D. thesis, Escola de Administração de Empresas de São Paulo da Fundação Getúlio Vargas, São Paulo, Brazil.

ONU Mulheres. 2016. Diretrizes para investigar, processar e julgar com perspectiva de gênero as mortes violentas de mulheres. In Entidade das Nações Unidas Para a Igualdade de Gênero e o Empoderamento das Mulheres-ONU Mulheres. Brasília: Mulheres-ONU Mulheres, p. 130. Available online: http://www.onumulheres.org.br/wpcontent/uploads/2016/04/diretrizes_feminicidio_FINAL.pdf (accessed on 20 June 2020).

Rolnik, Raquel, and Frúgoli J. R. Heitor. 2001. Reestruturação urbana da metrópole paulistana: A Zona Leste como território de rupturas e permanências. Cadernos Metrópole $2^{\circ}$ Sem 6: 43-66.

Saffioti, Heleieth. 2015. Gênero, Patriarcado, Violência. São Paulo: Expressão Popular e Fundação Perseu Abramo, Segunda Edição, ISBN 978-85-7743-2622.

São Paulo. 2016. $1^{a}$ Conferência Municipal De Desenvolvimento Rural Sustentável Da Cidade De São Paulo. Discutindo o rural na cidade de São Paulo. Relatório Final. p. 48. Available online: https://www.prefeitura. sp.gov.br/cidade/secretarias/upload/RelatorioFinalweb.pdf (accessed on 20 May 2020).

Siliprandi, Emma. 2009. Mulheres e Agroecologia: A Construção de Novos Sujeitos Políticos na Agricultura Familiar. Ph.D. thesis, Centro de Desenvolvimento Sustentável da Universidade de Brasília, Brasília-DF, Brazil.

Spradley, James. 2016. Participant Observation. Long Grove: Waveland Press, Inc., ISBN 1-4786-32089. First Published 1980. Taylor, Verta. 1995. Watching for Vibes: Bringing emotions into the study of feminist organizations. In Feminist Organizations: Harvest of the New Women's Movement. Edited by Myra Marx Ferree and Patricia Yancey Martin. Philadelphia: Temple University Press, pp. 223-33.

Waiselfisz, Julio Jacobo. 2015. Mapa da Violência 2015: Homicídio de mulheres no Brasil. FLACSO Brasil. p. 83. Available online: http://flacso.org.br/files/2015/11/MapaViolencia_2015_mulheres.pdf (accessed on 20 June 2020).

(C) 2020 by the authors. Licensee MDPI, Basel, Switzerland. This article is an open access article distributed under the terms and conditions of the Creative Commons Attribution (CC BY) license (http://creativecommons.org/licenses/by/4.0/). 